\title{
Natural Radioactivity in Some Food Crops from Bangka-Belitung Islands, Indonesia
}

\author{
Syarbaini ${ }^{*}$ A. Warsona and D. Iskandar \\ Center for Radiation Safety Technology and Metrology, National Nuclear Energy Agency \\ Jl. Lebak Bulus Raya No. 49, Jakarta 12440, Indonesia
}

\section{ARTICLE INFO}

Article history:

Received 21 October 2013

Received in revised form 22 April 2014

Accepted 28 April 2014

Keywords:

Natural Radioactivity

Food crops

Annual intake

Ingestion dose

Annual dose

\begin{abstract}
A B S T R A C T
Natural radioactivities of food crops are the main sources of internal radiation exposure in humans. Bangka Belitung islands of Indonesia has natural background radioactivity higher than normal area because of tin mining activities. The study was carried out to evaluate the natural radioactivity concentration in some food crops grown in Bangka and Belitung Islands. Food samples collected from Bangka and Belitung Islands were analysed by means of a gamma spectroscopy for natural radionuclides ${ }^{226} \mathrm{Ra},{ }^{232} \mathrm{Th}$ and ${ }^{40} \mathrm{~K}$. The annual intake of the food was estimated on the basis of their average annual consumption. Calculations were also made to determine the effective dose to an individual consuming such diets. The intakes of these radionuclides were calculated using the concentrations in Bangka Belitung foods and annual consumption rates of these food. Annual intakes of these radionuclides were as follows: ${ }^{226} \mathrm{Ra}=190.00 ;{ }^{232} \mathrm{Th}, 633.79$ and ${ }^{40} \mathrm{~K}=2065.10$ $\mathrm{Bq} /$ year. The annual internal dose resulting from ingestion of radionuclides in food was $0.205 \mathrm{mSv} /$ year which is very much lower than annual dose limit of $1 \mathrm{mSv}$ for general public. The radionuclides with highest consumption is ${ }^{40} \mathrm{~K}$ followed by ${ }^{232} \mathrm{Th}$ and ${ }^{226} \mathrm{Ra}$.
\end{abstract}

C 2014 Atom Indonesia. All rights reserved

\section{INTRODUCTION}

Bangka-Belitung is one of Indonesia provinces, includes two large islands, Bangka and Belitung, and several smaller ones, which located at east of Sumatra, northeast of South Sumatra province. Bangka-Belitung islands province is the $31^{\text {st }}$ Province in Indonesia, one of the newest provinces [1]. Bangka and Belitung Islands is known to have the geological potential of mineral resources, especially tin, with accessory minerals consisting of monazite, zircon, xenotim, ilmenite, magnetite and pyrite spread in almost all regions. Meanwhile, there are some others minerals resources like: quartz sand, building construction sand, kaolin, granite, clay and mountain stone [2].

Tin mining is the most significant activity in Bangka-Belitung islands. Indonesia is the second world's largest tin producer after China. Most of Indonesia's tin production comes from the BangkaBelitung islands. Tin mining and processing constitute a source of pollution to the environment. Environmental damage that occurred in the province of Bangka Belitung islands are very severe. This damage does not only occur on land but

\footnotetext{
* Corresponding author.

E-mail address: sarbaini@batan.go.id
}

also at sea. The land in Bangka Belitung is heavily damaged, with huge holes filled with standing turbid water everywhere. Bangka Belitung coast area is suffering from abrasion due to the number of holes at the bottom of the sea set off by coastal mining. The rapidly increasing number of illegal mining, is being as a large contributor to the destruction of the Bangka Belitung environment [3]. Heavy mineral processing from the tin mining exploration on earth's core has contributed a number of natural radioactivity to the environment. The mining, milling and processing of minerals lead to enhanced radiation exposures not only to the workers but also to the inhabitants of the mining and processing sites [4-7].

The analysis of radioactive minerals in foodstuff is an important part of the environmental monitoring program. The major pathways for the transfer of radionuclides to human beings are food crops. Therefore, the natural radionuclides are the largest contributor of the radiation doses received by the population who live around the tin mining activities area. Natural radionuclides are transferred and cycled through natural processes and between the various environmental compartments by entering into ecosystems and human food chains. Studies on radiation levels and radionuclide distribution in the environment provide vital 
radiological baseline information. Such information is essential in understanding human exposure from natural and man-made sources of radiation and necessary in establishing rules and regulation relating to radiation protection.

Radiation doses obtained due to the intake of food can be calculated from the amount of radionuclide deposited on foodstuff, the activity concentration of particular radionuclide in food per unit deposition, the consumption rate of the food products and the dose per unit activity ingested [8-10]. Measurement of concentrations of naturally occurring radionuclides $\left({ }^{226} \mathrm{Ra},{ }^{232} \mathrm{Th}\right.$ and $\left.{ }^{40} \mathrm{~K}\right)$ in the food collected from Bangka and Belitung islands enables one to assess the radiation doses received by the population. With the tin mining exploration activities, the level of radiation exposure to the environment and people live in Bangka Belitung may be increase. Generally, tin leaves some natural radionuclides which easily transfers from the mining location to its surrounding environment which goes up to the land surface or is absorbed down into the land water surface.

Since waste of tin mining has become a serious issue in Bangka Belitung, knowledge of the natural radioactivity levels in food crops due to tin mining activity is an important one in the assessment of overall human exposure to natural radiation associated with ${ }^{226} \mathrm{Ra},{ }^{232} \mathrm{Th}$ and ${ }^{40} \mathrm{~K}$. The objective of this work is to investigate the natural radioactivity levels $\left({ }^{226} \mathrm{Ra},{ }^{40} \mathrm{~K}\right.$ and $\left.{ }^{232} \mathrm{Th}\right)$ in some selected major food crops from BangkaBelitung islands and evaluate the implication on population radiation ingestion dose. This study provide a database of natural radionuclides activity concentrations in major food crops samples from environment of Bangka Belitung islands. This database is useful for further usage and research such as for estimation of transfer factors of certain radionuclides to food crops and risk assessment to human life. The data produced from this study not only become an asset to the Bangka-Belitung province as it will serve as a reference level against future nuclear activities in the region, but also contribute to the Indonesia Radioactivity Database. The data produced from this study will serve as reference levels and will be a useful guide against any radioactive contamination from future nuclear activities in Bangka Belitung province.

\section{EXPERIMENTAL METHODS}

\section{Sample collection}

The collected samples are some food crops grown and commonly consumed by the people of the Bangka Belitung islands. The vegetables, fruits and tuber samples were collected from local farmers and from vegetable gardens. Those samples are grown in the farms of this Bangka Belitung islands area and also available in the local markets. Each of samples was placed in the plastic bag and labeled with a permanent marker. All the samples were packed in a rigid plastic container and then transported to the environmental laboratory of the Center for Technology of Radiation Safety and Metrology for further treatments and measurement.

The fish samples were collected from local fishermen and local fish markets. The samples were cleaned to separate sands, weeds, and gravels, washed with water. Fish samples were generally gutted by the fishermen. All fish samples were then frozen and dispatched to the above Laboratory.

\section{Sample preparation}

In the laboratory, the vegetables and fruits and tuber samples were carefully washed under running water and the in distilled water to remove all the attached sand and dust particles. Those sample were cut to pieces with a knife and were allowed to dry to a constant weight at room temperature. The samples were then weighed and ashed at $450{ }^{\circ} \mathrm{C}$ to remove organic matter [11].

Fish samples were allowed to thaw out naturally. Samples were rinsed under a cold running tap to remove fish scales and any extraneous particulate material. Flesh and muscle parts were removed from bones, mixed in the chopper and prepared as samples. They were then filleted. The fillets were again rinsed to remove extraneous material, minced, dried to constant weight. Fish samples were weighed and dried in an oven at about $100{ }^{\circ} \mathrm{C}$ and reduced to ashes in a muffle furnace at $350-400{ }^{\circ} \mathrm{C}$ for about $24 \mathrm{~h}$ [12].

\section{Radioactivity measurements}

Each of the prepared sample was transferred to airtight cylindrical plastic screw-cap vial. The vials were sealed and allowed to stand for at least 4 weeks for secular equilibrium to be established between the long-lived parent nuclides of ${ }^{226} \mathrm{Ra}$ and ${ }^{232} \mathrm{Th}$, and their short-lived daughters. The measurement of the radionuclides in the prepared samples were carried out by using ORTEC P-type coaxial high purity Germanium (HPGe) detector with a relative efficiency of $60 \%$ and a resolution of $1.95 \mathrm{keV}$ (full width at half maximum) for the peak of $1.33 \mathrm{keV}$. The detector was coupled to a multi channel computer based 
analyzer. The gamma ray spectrum is recorded using a Personal Computer based 4096 channel analyzer and processed using ORTEC Vission-32 Gamma spectrum analysis computer software. The detector is located inside a cylindrical lead shield of $10.1 \mathrm{~cm}$ thickness with internal diameter of $28 \mathrm{~cm}$ and height of $40 \mathrm{~cm}$. The lead shield is lined with various layers of tin and copper each of 0.5 and $1.6 \mathrm{~mm}$ thick respectively.

The detection efficiency calibration of the system for the determination of radionuclides in the prepared samples was carried out using certified standard source $\left({ }^{152} \mathrm{Eu}\right)$ and International Atomic Energy Agency (IAEA) reference materials prepared in geometrical shape and composition to simulate the samples' matrix. The measurements were carried out in the counting room located in the basement of laboratory building. The measurement time for samples and background was 17 hours. The background counts was used to correct the net peak area of gamma rays of measured isotopes. Quality assurance was additionally guaranteed by regular participations in national and international intercompararison exercises.

The gamma energy peaks $352 \mathrm{keV}$ of ${ }^{214} \mathrm{~Pb}$ and $609.31 \mathrm{keV}$ of ${ }^{214} \mathrm{Bi}$ were used to determine ${ }^{226} \mathrm{Ra}$. The gamma energy peaks of $238.6 \mathrm{keV}$ from ${ }^{212} \mathrm{~Pb}, 911.2$ and $969 \mathrm{keV}$ gamma energy peak from ${ }^{228} \mathrm{Ac}$ and $583 \mathrm{keV}$ gamma energy peak from ${ }^{208} \mathrm{Tl}$ were used to determine the ${ }^{232} \mathrm{Th}$, and that of ${ }^{40} \mathrm{~K}$ was determined from the gamma energy peak of $1460.83 \mathrm{keV}$.

The activity concentrations (A) of ${ }^{226} \mathrm{Ra},{ }^{232} \mathrm{Th}$ and ${ }^{40} \mathrm{~K}$ in $\mathrm{Bq} \mathrm{kg}{ }^{-1}$ for the samples were determined using the following expression $[13,14]$ :

$$
A=\frac{N_{e}}{\varepsilon_{f} P_{\gamma} t_{C} M}
$$

where; $\mathrm{N}_{\mathrm{e}}=$ net counts of a peak at energy $\mathrm{E}$, $\varepsilon_{\mathrm{f}}=$ the counting efficiency of the detector system at energy $\mathrm{E}, \mathrm{P}_{\gamma}=$ the gamma ray emission probability (gamma yield) at energy $\mathrm{E}, \mathrm{t}_{\mathrm{c}}=$ sample counting time, and $\mathrm{M}=$ mass of sample $(\mathrm{kg})$. If there is more than one peak in the energy analysis range for a radionuclide, then an attempt to average the peak activities is made. The results is then the weighted average radionuclide activity.

\section{Calculation of effective dose}

In order to assess the ingestion dose of radionuclides, it is necesarry to determine the annual activity intake per inhabitant for each ingested radionuclide. The intake of radionuclides by ingestion is well described by the ICRP Human Alimentary Tract Model $[15,16]$. To derive ingested dose, the ingested annual activity of each radionuclide is multiplied by its dose conversion coefficient [17-19]. Finally, the total ingestion dose is obtained by summing the contributions of all radionuclides.

The annual intakes $(\mathrm{Q})$ for ${ }^{226} \mathrm{Ra},{ }^{232} \mathrm{Th}$ and ${ }^{40} \mathrm{~K}$ from foodstuffs in the present work were determined by using the activity concentrations (A) in foods and the annual food consumption rates (F) by the Bangka - Belitung islands population based on the National Socio-Economic Survey, 2012 [20]. Estimation of the annual internal effective dose $(\mathrm{H})$ was calculated by using the following equations [17-19] :

$$
\mathrm{H}=\mathrm{A} \times \mathrm{F} \times \mathrm{IDCF}
$$

where $\mathrm{H}$ is the annual effective dose $\left(\mathrm{Sv}^{-1}\right)$ due to ingestion of radionuclides from the consumption of foodstuffs, $\mathrm{A}$ is the concentration of radionuclides in the ingested foodstuffs $\left(\mathrm{Bq} \mathrm{kg}^{-1}\right), \mathrm{F}$ is the annual intake of foodstuff $\left(\mathrm{kg} \mathrm{y}^{-1}\right)$, and IDCF is the ingested dose conversion factor for radionuclides $\left(\mathrm{Sv} \mathrm{Bq}{ }^{-1}\right)$. IDCF values used for ${ }^{226} \mathrm{Ra},{ }^{232} \mathrm{Th}$ and ${ }^{40} \mathrm{~K}$ are 0.28 , 0.22 and $6.2 \times 10^{-3} \mu \mathrm{Sv} \mathrm{Bq}^{-1}$ respectively.

\section{RESULTS AND DISCUSSION}

\section{Radionuclides concentrations in major foods from Bangka Belitung}

The results of the activity concentration measurements in the vegetables, fruits and tuber collected from Bangka Belitung province are presented in Table 1. Among the all food crops types collected and analyzed, the activity concentration of ${ }^{226} \mathrm{Ra}$ varies between $2.69 \pm$ $0.51 \mathrm{~Bq} / \mathrm{Kg}$ (Swamp cabbage) and $12.18 \pm$ $2.63 \mathrm{~Bq} / \mathrm{Kg}$ (Cassava leaf). The ${ }^{232} \mathrm{Th}$ activity in food crops varies between $8.20 \pm 1.09 \mathrm{~Bq} / \mathrm{Kg}$ (Swamp cabbage) and $46.00 \pm 3.53 \mathrm{~Bq} / \mathrm{Kg}$ (Jackfruit). The activity concentration of ${ }^{40} \mathrm{~K}$ ranged from $40.12 \pm 3.81 \mathrm{~Bq} / \mathrm{Kg}$ (Cucumber) to $125.23 \pm$ $11.80 \mathrm{~Bq} / \mathrm{Kg}$ (Swamp cabbage). The concentration of ${ }^{40} \mathrm{~K}$ was found to be very high compared to ${ }^{226} \mathrm{Ra}$ and ${ }^{232} \mathrm{Th}$. It is may be attributed to poor migration charateristics of radium and thorium from the soil to the vegetables in the concerned environment [10]. Potasium is a macronutrient, so the concentration may be high. It may be expected that the soil characteristics favour the mobilization of potasium and its subsequent migration into the plant. 
The level of ${ }^{40} \mathrm{~K}$ in Jackfruit was $65.83 \pm$ $3.93 \mathrm{~Bq} / \mathrm{Kg}$, and $85.27 \pm 8.04 \mathrm{~Bq} / \mathrm{Kg}$ for Banana and for cassava $40.40 \pm 5.79 \mathrm{~Bq} / \mathrm{Kg}$. The activity concentration of ${ }^{40} \mathrm{~K}$ was more in vegetables and fruits when compared to tubers (cassava).

Table 1. Activity concentration of natural radionuclides in vegetables, fruits and tuber.

\begin{tabular}{lccc}
\hline \multicolumn{1}{c}{$\begin{array}{l}\text { Type of } \\
\text { sample }\end{array}$} & \multicolumn{3}{c}{ Activity concentration (Bq/kg fresh-weight) } \\
\cline { 2 - 4 }${ }^{226} \mathrm{Ra}$ & \multicolumn{2}{c}{${ }^{232} \mathrm{Th}$} & ${ }^{40} \mathrm{~K}$ \\
\hline $\begin{array}{l}\text { Vegetables } \\
\text { Spinach }\end{array}$ & $7.47 \pm 0.50$ & $19.91 \pm 2.72$ & $69.80 \pm 6.59$ \\
$\begin{array}{l}\text { Swamp } \\
\text { cabbage }\end{array}$ & $2.69 \pm 0.51$ & $8.20 \pm 1.09$ & $125.23 \pm 11.80$ \\
$\begin{array}{l}\text { Mustard } \\
\text { greens }\end{array}$ & $2.77 \pm 0.65$ & $8.82 \pm 1.18$ & $110.56 \pm 10.42$ \\
String beans & $11.35 \pm 1.62$ & $26.37 \pm 3.96$ & $64.31 \pm 6.12$ \\
Cucumber & $9.55 \pm 1.20$ & $18.95 \pm 2.15$ & $40.12 \pm 3.81$ \\
Cassava leaf & $12.18 \pm 2.63$ & $39.19 \pm 1.31$ & $42.81 \pm 10.19$ \\
$\begin{array}{l}\text { Fruits } \\
\text { Jackfruit }\end{array}$ & $10.85 \pm 1.18$ & $46.00 \pm 3.53$ & $65.83 \pm 3.93$ \\
Banana & $5.45 \pm 1.48$ & $18.60 \pm 3.29$ & $85.27 \pm 8.04$ \\
Tuber & & & \\
Cassava & $3.68 \pm 0.80$ & $22.10 \pm 2.70$ & $40.40 \pm 5.79$ \\
\hline
\end{tabular}

Nine types of fish samples were investigated for ${ }^{226} \mathrm{Ra},{ }^{232} \mathrm{Th}$ and ${ }^{40} \mathrm{~K}$ and the results are listed in Table 2. It was found that the maximum level of ${ }^{226} \mathrm{Ra}$ was $11.11 \pm 1.44 \mathrm{~Bq} / \mathrm{kg}$ detected in Mozambique tilapia, while the minimum level of $<0.01$ was detected in Milkfish. ${ }^{232} \mathrm{Th}$ was detected in all fish samples with the maximum level of $44.62 \pm 4.41 \mathrm{~Bq} / \mathrm{kg}$ detected in Mozambique tilapia, while the minimum level of $0.23 \pm$ $0.05 \mathrm{~Bq} / \mathrm{kg}$ was detected in Red snapper. The levels of ${ }^{40} \mathrm{~K}$ in fish sampels were distributed from the lowest level to the highest level. The highest concentration was $90.84 \pm 8.61 \mathrm{~Bq} / \mathrm{kg}$, recorded in Mud crab, followed by Milkfish and Shrimp with values of $64.58 \pm 6.20 \mathrm{~Bq} / \mathrm{Kg}$ and $57.60 \pm$ $5.57 \mathrm{~Bq} / \mathrm{Kg}$ respectively. The low concentration were $15.02 \pm 1.45 \mathrm{~Bq} / \mathrm{Kg}$ and $20.97 \pm 2.01 \mathrm{~Bq} / \mathrm{Kg}$, detected in Cockle and Catfish respectively. Mozambique tilapia was found as dominant type of fish in absorb of ${ }^{226} \mathrm{Ra},{ }^{232} \mathrm{Th}$ and also ${ }^{40} \mathrm{~K}$. This is due to the fact that the Mozambique tilapia is type of freshwater fish collected from the river. Most tinmining areas have rich monazite and xenotime. These two minerals have rich natural radionuclides, particularly uranium, and thorium series and potassium such as ${ }^{226} \mathrm{Ra},{ }^{232} \mathrm{Th}$ and ${ }^{40} \mathrm{~K}$. Therefore, rivers passing through these areas would carry in their load traces of these radionuclides. Then the radionuclides could enter the food chain in the aquatic system which involves the phytoplankton (algae), zooplankton (microorganism) and other aquatic life such as Mozambique tilapia [21].
Table 2. Activity concentration of natural radionuclides in fish.

\begin{tabular}{|c|c|c|c|}
\hline \multirow{2}{*}{$\begin{array}{l}\text { Type of } \\
\text { sample }\end{array}$} & \multicolumn{3}{|c|}{ Activity concentration (Bg $/ \mathrm{kg}$ fresh-weight) } \\
\hline & ${ }^{226} \mathrm{Ra}$ & ${ }^{232} \mathrm{Th}$ & ${ }^{40} \mathrm{~K}$ \\
\hline Yellow tail & $0.80 \pm 0.11$ & $0.46 \pm 0.10$ & $38.83 \pm 3.89$ \\
\hline Mackerel & $0.36 \pm 0.01$ & $0.74 \pm 0.14$ & $45.24 \pm 12.10$ \\
\hline Milkfish & $<0.01$ & $17.81 \pm 4.21$ & $64.58 \pm 6.20$ \\
\hline $\begin{array}{l}\text { Mozambique } \\
\text { tilapia }\end{array}$ & $11.11 \pm 1.44$ & $44.62 \pm 4.41$ & $36.48 \pm 3.51$ \\
\hline Catfish & $3.81 \pm 0.71$ & $2.81 \pm 0.64$ & $20.97 \pm 2.01$ \\
\hline Red snapper & $0.12 \pm 0.01$ & $0.23 \pm 0.05$ & $47.60 \pm 5.57$ \\
\hline Shrimp & $4.27 \pm 1.04$ & $18.36 \pm 2.32$ & $57.60 \pm 5.57$ \\
\hline Mud crab & $0.17 \pm 0.05$ & $8.06 \pm 1.54$ & $90.84 \pm 8.61$ \\
\hline Cockle & $0.10 \pm 0.01$ & $2.50 \pm 0.74$ & $15.02 \pm 1.45$ \\
\hline
\end{tabular}

\section{Annual radioisotopes intakes from Bangka and Belitung islands foods}

Using the results of activities concentration of vegetables, fruits, tuber and fish presented in Tables 1 and 2 and the data on food consumption rate reported the Indonesia Agency of Statistics [20], the intake of radionuclides by the population of Bangka-Belitung province was estimated. The results are presented in Table 3 and 4 . The corresponding food consumption rate used to evaluate the intake of radionuclides are also given in the tables. It can be seen from the tables that the radionuclides with the highest annual intake was ${ }^{40} \mathrm{~K}$ $(2065.10 \mathrm{~Bq})$ followed by ${ }^{232} \mathrm{Th}(633.79 \mathrm{~Bq})$ and ${ }^{226} \mathrm{Ra}(190.00 \mathrm{~Bq})$. The food crops with the highest amount of intake of radionuclides is vegetable, followed by tuber, fruit and fish. The results show that vegetables predominantly absorb ${ }^{40} \mathrm{~K},{ }^{232} \mathrm{Th}$ and ${ }^{226} \mathrm{Ra}$ radionuclides. This is due to the fact that vegetables have the capability to absorb elemental isotopic through root uptake and from the leaves as a result of atmospheric deposit. Among the all vegetables types analyzed, the highest amount of intake is Swamp cabbage, followed by Spinach and String beans, while the fish with the highest amount of intake is Shrimp, followed by Mozambique tilapia and Milkfish.

Table 3. The annual radionuclide intake for ${ }^{226} \mathrm{Ra},{ }^{232} \mathrm{Th}$ and ${ }^{40} \mathrm{~K}$ from vegetables, fruits and tuber.

\begin{tabular}{|c|c|c|c|c|}
\hline \multirow{2}{*}{ Type of food } & \multirow{2}{*}{$\begin{array}{l}\text { Consumption } \\
\operatorname{rate}^{(\mathrm{a})}\left(\mathrm{kg} \mathrm{y}^{-1}\right)\end{array}$} & \multicolumn{3}{|c|}{ Activity concentration $(\mathrm{Bq})$} \\
\hline & & ${ }^{226} \mathrm{Ra}$ & ${ }^{232} \mathrm{Th}$ & ${ }^{40} \mathrm{~K}$ \\
\hline \multicolumn{5}{|l|}{ Vegetables } \\
\hline Spinach & 3.80 & 28.39 & 75.66 & 265.24 \\
\hline Swamp cabbage & 4.47 & 12.02 & 36.65 & 559.78 \\
\hline Mustard greens & 1.46 & 4.04 & 12.88 & 161.42 \\
\hline String beans & 2.76 & 31.33 & 72.78 & 177.50 \\
\hline Cucumber & 1.56 & 14.90 & 29.56 & 62.59 \\
\hline Cassava leaf & 2.65 & 32.28 & 103.85 & 113.45 \\
\hline \multicolumn{5}{|l|}{ Fruits } \\
\hline Jackfruit & 1.20 & 13.02 & 55.20 & 79.00 \\
\hline Banana & 1.61 & 8.77 & 29.95 & 137.28 \\
\hline \multicolumn{5}{|l|}{ Tuber } \\
\hline Cassava & 3.48 & 12.81 & 76.91 & 140.59 \\
\hline \multicolumn{2}{|c|}{ Total intake $(\mathrm{Bq})$} & 157.56 & 493.44 & 1696.84 \\
\hline
\end{tabular}

(a) according to a survey conducted by the Indonesia Agency of Statistics for Bangka-Belitung province. 
Table 4. The annual radionuclide intake for ${ }^{226} \mathrm{Ra},{ }^{232} \mathrm{Th}$ and ${ }^{40} \mathrm{~K}$ from fish.

\begin{tabular}{lcccc}
\hline \multirow{2}{*}{ Type of food } & $\begin{array}{c}\text { Consumption } \\
\text { rate }\left(\mathrm{kg} \mathrm{y}^{-1}\right)\end{array}$ & \multicolumn{3}{c}{ Activity concentration $(\mathrm{Bq})$} \\
\cline { 3 - 5 } & 0.36 & 0.29 & 0.17 & 13.98 \\
\hline Yellow tail & 0.16 & 0.06 & 0.12 & 7.24 \\
Mackerel & 1.14 & - & 20.30 & 73.62 \\
Milkfish & 1.25 & 13.89 & 55.78 & 45.60 \\
Mozambique tilapia & 1.09 & 4.15 & 3.06 & 22.86 \\
Catfish & 0.21 & 0.03 & 0.05 & 10.00 \\
Red snapper & 3.28 & 14.01 & 60.22 & 188.93 \\
Shrimp & 0.05 & 0.01 & 0.40 & 4.54 \\
Mud crab & 0.10 & 0.01 & 0.25 & 1.50 \\
Cockle & \multicolumn{2}{c}{${ }^{232} \mathrm{Th}$} & ${ }^{40} \mathrm{~K}$ \\
\hline \multicolumn{2}{c}{ Total intake $(\mathrm{Bq})$} & 32.44 & 140.35 & 368.26 \\
\hline
\end{tabular}

\section{Annual internal dose}

Using the activity intake results presented in Table 3 and 4, the annual effective internal dose due to the ingestion of ${ }^{226} \mathrm{Ra},{ }^{232} \mathrm{Th}$ and ${ }^{40} \mathrm{~K}$ radionuclides are calculated. The results are given in Table 5 and 6 . The recommended dose conversion coefficient for ${ }^{226} \mathrm{Ra},{ }^{232} \mathrm{Th},{ }^{40} \mathrm{~K}$ are $0.28,0.22$ and $0.0062 \mu \mathrm{Sv} / \mathrm{Bq}$, respectively [17-19]. The total internal dose of ${ }^{226} \mathrm{Ra},{ }^{232} \mathrm{Th},{ }^{40} \mathrm{~K}$ in Bangka Belitung foods were estimated to be $0.053,0.139$ and $0.013 \mathrm{mSv} /$ year. The total annual internal dose from ingestion of food samples in this study was $0.205 \mathrm{mSv} /$ year. It can be seen that this doses is lower than annual dose limit of $1 \mathrm{mSv}$ for general public [19].

Table 5. The estimated annual internal dose for ${ }^{226} \mathrm{Ra},{ }^{232} \mathrm{Th}$ and ${ }^{40} \mathrm{~K}$ from vegetables, fruits and tuber.

\begin{tabular}{lccc}
\hline \multirow{2}{*}{ Type of food } & \multicolumn{3}{c}{ Activity concentration $(\mu \mathrm{Sv})$} \\
\cline { 2 - 4 } & ${ }^{226} \mathrm{Ra}$ & ${ }^{232} \mathrm{Th}$ & ${ }^{40} \mathrm{~K}$ \\
\hline Spinach & 7.948 & 16.645 & 1.644 \\
Swamp cabbage & 3.367 & 8.064 & 3.471 \\
Mustard greens & 1.132 & 2.833 & 1.001 \\
String beans & 8.771 & 16.012 & 1.100 \\
Cucumber & 4.171 & 6.504 & 0.388 \\
Cassava leaf & 9.038 & 22.848 & 0.703 \\
Jackfruit & 3.646 & 12.144 & 0.490 \\
Banana & 2.457 & 6.588 & 0.851 \\
Cassava & 3.586 & 16.920 & 0.872 \\
\hline \multicolumn{1}{c}{ Total } & 44.116 & 108.557 & 10.520 \\
\hline
\end{tabular}

Tabel 6. The estimated annual internal dose for ${ }^{226} \mathrm{Ra},{ }^{232} \mathrm{Th}$ and ${ }^{40} \mathrm{~K}$ from fish.

\begin{tabular}{lccc}
\hline \multirow{2}{*}{ Type of food } & \multicolumn{3}{c}{ Activity concentration $(\mu \mathrm{Sv})$} \\
\cline { 2 - 4 } & ${ }^{226} \mathrm{Ra}$ & ${ }^{232} \mathrm{Th}$ & ${ }^{40} \mathrm{~K}$ \\
\hline Yellow tail & 0.081 & 0.036 & 0.087 \\
Mackerel & 0.016 & 0.026 & 0.045 \\
Milkfish & - & 4.467 & 0.456 \\
Mozambique tilapia & 3.889 & 12.271 & 0.283 \\
Catfish & 1.163 & 0.674 & 0.142 \\
Red snapper & 0.007 & 0.011 & 0.062 \\
Shrimp & 3.922 & 13.249 & 1.171 \\
Mud crab & 0.002 & 0.089 & 0.028 \\
Cockle & 0.003 & 0.055 & 0.009 \\
\hline \multicolumn{1}{c}{ Total } & 9.082 & 30.876 & 2.283 \\
\hline \multicolumn{1}{c}{}
\end{tabular}

\section{CONCLUSION}

The study on the activity concentration of radionuclides ${ }^{226} \mathrm{Ra},{ }^{232} \mathrm{Th}$, and ${ }^{40} \mathrm{~K}$ in some food crops that are regularly consumed by the population of Bangka Belitung province show that the highest value of concentration was vegetables, followed by fruits and fish. Among the all vegetables samples, the highest activity concentration of radionuclides was Swamp cabbage and Mustard greens, followed by String beans, Spinach and Cassava leaf. According to this study, fruits have maximum radionuclides concentration compared to tubers (Cassava). Among the all fish samples, the highest activity concentration of radionuclides was Mozambique tilapia and Mud crab, followed by Shrimp.

Based on the activity concentration of radionuclides and the data on food consumption rate, the annual intakes of these radionuclides were estimated higher in Swamp cabbage, Spinach, String beans, Cassava leaf, Cassava, Shrimp and Mozambique tilapia. For Spinach, String beans, and Cassava leaf, the high radionuclides intake values were not only due to high radionuclides concentration but also due to the high consumption rate. Meanwhile, the estimation of annual effective internal dose received by the members of the public from consumption of these food crops, the main contributors to the intake internal dose was Cassava leaf, Spinach and String beans, followed by Shrimp and Mozambique tilapia.

The annual internal dose received by general public living in Bangka-Belitung islands area due to the consumption of the common vegetables, fruits, tuber and fish is $0.205 \mathrm{mSv} / \mathrm{year}$. This dose is lower than annual dose limit of $1 \mathrm{mSv}$ for general public.

\section{ACKNOWLEDGMENT}

The authors would like to thank Indonesian State Ministry of Research and technology for funding the project through the research block grant program fiscal year 2010 .

\section{REFERENCES}

1. Anonymous, Law of the Republic of Indonesia Number 27 of 2000 Concerning Establishment of The Province Bangka Belitung, Jakarta (2000) 1.

2. M.O. Schwartz, S.S. Rajah, A.K. Askury, et al., Earth-Science Reviews 38 (1995) 95. 
3. M. Sidabukke, Illegal Tin Minning at Protection Forest Area (Case Study at Protection Forest Area of Sepang Mountain, Badau, Bangka Belitung), Ph.D. Thesis, University of Indonesia (2011).

4. A.M. Arogunjo, V. Hollriegl, A. Giussani, et al., J. Environ. Radioact. 100 (2009) 232.

5. I.G.E. Ibeanu, J. Environ. Radioact. 64 (2003) 59.

6. N.N. Jibiri, I.P. Farai and S.K. Alausa, J. Environ. Radioact. 94 (2007) 331.

7. I. Bahari, N. Mohsen and P. Abdullah, J. Environ. Radioact. 95 (2007) 61.

8. N.N. Jibiri and T.H. Abiodun, J. Nucl. Sci. Technol. 2 (2012) 106.

9. N.N Jibiri, I.P. Farai and S.K. Alausa, Radiat. Environ. Biophys. 46 (2007) 53.

10. D.I. Jwanbot, M.M. Izam and G.G. Nyam, Journal of Natural Sciences Research 2 (6) (2012) 76.

11. Anonymous, Measurement of Radionuclides in Food and the Environment, Technical Reports Series No. 295, IAEA, Vienna (1989) 22.

12. S.N.A. Tahir, M. Ayub and M.Z. Khan, Health Phys. 98 (2010) 741.

13. G.F. Knoll, Radiation Detection and Measurements, $3^{\text {rd }}$ ed., John Wiley \& Sons, Inc., New York (2000) 65.
14. H.A. Al-Sulaiti, Determination of Natural Radioactivity Levels in the State of Qatar Using High-Resolution Gamma-ray Spectrometry, Ph.D. Thesis, Surrey University (2011) 77.

15. Anonymous, Limits for the intake of radionuclides by workers, part 1 . Publication 30, ICRP, Pergamon Press, Oxford (1979) 12.

16. Anonymous, Human alimentary tract model for radiological protection, Publication 100, ICRP, Pergamon Press, Oxford (2006) 31.

17. Anonymous, Age-dependent doses to members of the public from intake of radionuclides, part 2. Ingestion dose coeficients, Publication 67, ICRP, Pergamon Press, Oxford (1994) 6.

18. Anonymous, Age-dependent doses to members of the public from intake of radionuclides, part 3. Ingestion dose coeficients, Publication 69, ICRP, Pergamon Press, Oxford (1995) 7.

19. Anonymous, Sources and Effects of Ionizing Radiation, United Nations Scientific Committee on the Effects of Atomic Radiation, United Nations publication, New York (2000) 127.

20. Anonymous, Executive Summary of Consumption and Expenditure of Indonesia, Based on Susenas September 2012, National Socio Economic Survey Statistic Indonesia Agency (2013) 479.

21. A.M. Yusof, M.N. Mahat, N. Omar, et al., Ecological Engineering 16 (2001) 405. 